\title{
Biochar amendment of grassland soil may promote woody encroachment by Eastern Red Cedar
}

\author{
Ramesh Laungani $^{1 *}$, Kenneth Elgersma ${ }^{2}$, Kristin McElligott ${ }^{3}$, Maria Juarez ${ }^{1 \uparrow}$, Tyler \\ Kuhfahl ${ }^{19}$
}

${ }^{1}$ Doane University Biology Department 1014 Boswell Avenue Crete, Nebraska 68333. ${ }^{2}$ University of Northern Iowa Department of Biology 144 McCollum Hall Cedar Falls $50614{ }^{3}$ Virginia Tech

Department of Forest Resources \& Environmental Conservation 228 Cheatham Hall (0324) Blacksburg, VA

24061

"Undergraduate authors

\begin{abstract}
Although carbon $(\mathrm{C})$ additions to soil have been used in restoration to combat invasive species through changes in soil nitrogen $(\mathrm{N})$ availability, carbon amendments to soil derived from plant material can impact soil $\mathrm{N}$ availability in a species-specific manner. As such, amendment-driven feedbacks on $\mathrm{N}$ may impact invasive species success and woody encroachment. Soil amendments like biochar, which is often added to soil to increase C storage in grassland systems, may unintentionally encourage woody encroachment into these grasslands by changing soil $\mathrm{N}$ dynamics. Few studies have examined biochar impacts on non-agricultural species, particularly invasive species. Woody encroachment of Eastern Red Cedar (Juniperus virginiana) into grasslands provides an ideal context for examining the impact of biochar in grasslands. In the greenhouse, we examined the effect of biochar or leaf litter derived from native and exotic grasses on J.virginiana seedling growth. Juniperus virginiana seedlings grew $40 \%$ bigger in biochar amended soil as compared to seedlings grown in litter amended soil. Additionally, we found a more than 2 order of magnitude increase in available $\mathrm{NH}_{4}^{+}$in the biochar treatments compared to the litter amended soils. Furthermore we found that biochar feedstock type did not have an impact on the effect of biochar, as both native and exotic grass biochar had similar impacts on soil N levels and $J$. virginiana growth. Our work suggests that once grassland litter is converted to biochar, species impacts on soil $\mathrm{N}$ may disappear. In conclusion, our data suggests soil amendments of biochar may encourage woody encroachment into grasslands.
\end{abstract}

Keywords: Invasion, biochar, plant-soil feedback, nitrogen, litter, immobilization 


\section{Introduction}

Invasive species management can pose a significant challenge for restoration projects, with invasive species often leading to the loss of native plant species from an ecosystem. A key driver of invasive species success is often excess availability of limiting soil resources such as nitrogen $(\mathrm{N})$ (Siemann and Rogers 2003, Laungani and Knops 2009). One management practice that has been widely studied to combat the spread of invasive species through changes in soil $\mathrm{N}$ is the intentional addition of carbon (C) amendments to soil (Blumenthal et al. 2003). The addition of C to soil (often in the form of a sawdust/sucrose mixture) can result in microbial immobilization of inorganic soil $\mathrm{N}$, which is then unavailable for plant uptake and growth,ultimately impacting the success of the invasive species (Laungani and Knops 2009).

Intentional addition of $\mathrm{C}$ amendments to soil has also been utilized to increase long-term $\mathrm{C}$ storage in soils. In particular, addition of biochar, the carbon-rich product of heating plant material to high temperatures with little to no oxygen (pyrolysis), is used as a soil amendment to improve soil $\mathrm{C}$ storage in both agricultural and natural ecosystems (Ohsowski et al. 2012, Biederman and Harpole 2013, Lehmann et al. 2015). However, additions of biochar have been shown to both increase and decrease soil $\mathrm{N}$ availability as well as a number of other soil properties such as $\mathrm{pH}$ and cation exchange capacity (McElligott et al. 2011, Clough et al. 2013). As such, these biochar driven changes in soil $\mathrm{N}$ availability can significantly impact plant performance (Biederman and Harpole 2013). Additionally, the impact of biochar on plant performance can be dependent on the feedstock that is used to make the biochar. A recent study by van de Voorde et al. (2014b) examined the impact of biochar on plant growth made from a variety of grassland species and found species-specific effects and dif- fering impacts of pyrolyzed versus non-pyrolyzed feedstock (i.e. litter) on plant growth. Other recent studies showed that the addition of biochar to soils can alter the composition of grassland ecosystems (Schimmelpfennig et al. 2014, van de Voorde et al. 2014a). Taken together, this suggests that biochar additions to soil have the potential to induce either positive or negative feedbacks on plant performance in general and therefore may also impact invasive species success. Additionally, understanding how biochar amendments impact invasive species growth is particularly important if soil amendments like biochar are to be used as a management tool in either agricultural (Curaqueo et al. 2014) or non-agricultural grassland ecosystems (Ohsowski et al. 2012, Schimmelpfennig et al. 2014, van de Voorde et al. 2014a). Unfortunately the impact of biochar additions on the success of invasive plants remains understudied (Adams et al. 2013). Given the significant impact that $\mathrm{N}$ availability can have on the success of invasive species (Blumenthal et al. 2003, Laungani and Knops 2009) and the growing interest in biochar additions to natural systems for C storage (Ohsowski et al. 2012), we examined the impact of different grassland biochars on the growth of an invasive species and their impact on $\mathrm{N}$ availability.

In the Great Plains of North America, the simultaneous invasion of Bromus inermis, an exotic grass, and woody encroachment of Juniperus virginiana into grasslands provide an ideal context for examining biochar-driven feedbacks on plant growth and invasive species success. Bromus inermis is an exotic grass species that has come to dominate a number of grassland ecosystems in the United States (Vinton and Goergen 2006). Similarly, J. virginiana is a native invasive tree that is rapidly 
expanding in prairies, streams, and farmland ecosystems and transforming grassland ecosystems into closed canopy woodland (Knapp et al. 2008). While the expansion of J. virginiana has been largely attributed to fire suppression in the Great Plains, other factors such as inorganic soil $\mathrm{N}$ availability may also impact its success (Norris et al. 2007).

While other work has demonstrated that $B$. inermis litter can alter $\mathrm{N}$ cycling and $\mathrm{N}$ availability to the plant community (Vinton and Goergen 2006), the impact of $B$. inermis biochar on $\mathrm{N}$ availability is still unknown. The concurrent expansion of these two species allows us to examine whether the biochar of $B$. inermis, can enhance the success of $J$. virginiana, via $B$. inermis biochar additions to the soil. In order to examine the potential for $B$. inermis biochar to facilitate the growth of $J$. virginiana, we exposed $J$. virginiana seedlings to a variety of soil conditions: 1$)$ soil without $B$. inermis tissue (unamended soil), 2) soil with $B$. inermis biochar, and 3 ) soil with $B$. inermis leaf litter (nonbiochar). Additionally, we exposed J. virginiana seedlings to litter and biochar of a native dominant grass species, Schizachyrium scoparium, in order to determine whether any observed effects of litter or biochar were $B$. inermis specific.

Our experimental design allowed us to separate the impact of grass species identity (B. inermis or $S$. scoparium) from amendment type (biochar or litter) on inorganic $\mathrm{N}$ availability and $J$. virginiana growth. For example, if the addition of biochar (regardless of feedstock species) increases inorganic $\mathrm{N}$ availability and $J$. virginiana growth compared to litter-amended soils, that suggests that the addition of biochar, as a management tool for soil C storage, may have unintended consequences for species invasion.

\section{Materials and Methods}

\section{1|. Soil amendment treatments}

Both $B$. inermis grass litter and $S$. scoparium grass litter was collected from Spring Creek Prairie Audubon Center in Denton, NE $\left(40.69^{\circ} \mathrm{N}\right.$, $\left.96.85^{\circ} \mathrm{W}\right)$. Leaf litter was air-dried to a constant weight at $65{ }^{\circ} \mathrm{C}$ for making biochar soil amendments and for use as litter soil amendments.

Juniperus virginiana seedlings were grown in unamended control soil $(\mathrm{n}=10)$ or soil amended with one of five different soil amendments: 1) invasive B. inermis leaf litter ( $\mathrm{n}=10$; abbreviated $\mathrm{BL}$ in the figures), 2) native $S$. scoparium leaf litter ( $\mathrm{n}=10$; abbreviated $\mathrm{NL}$ in the figures), 3) B. inermis leaf litterbiochar ( $\mathrm{n}=8$; abbreviated BB in the figures), 4) S. scoparium leaf litter biochar ( $\mathrm{n}=10$; abbreviated NB in the figures), or 5) sawdust ( $\mathrm{n}=10$; collected from a local lumber mill; abbreviated SD in the figures). Schizachryium scoparium litter and biochar was used because it is a common native dominant species at Spring Creek Prairie Audubon Center and other natural areas throughout the region (Laungani pers. obs). Sawdust was utilized as a soil amendment because it has been used as a soil amendment for invasive species control in many other studies (Blumenthal et al. 2003).

Leaf litter of each species was pulverized using a common household blender. Biochar of each grass was produced by packing tin cans with $B$. inermis leaf litter or S. scoparium leaf litter, sealing the cans with aluminum foil to deprive the leaves of oxygen, and heating the cans in an oven at $350^{\circ} \mathrm{C}$ for four hours (Lehmann and Joseph 2009). 
Charring was visually confirmed when the plant material turned to a charcoal black color indicating that the cans were sealed tight with minimal oxygen present. The biochar was then coarsely ground by hand before application to soil. All amendments were $<2$ $\mathrm{mm}$ in size and there were no visible differences were seen between the particle sizes of the various soil amendments. Soil (0-15 cm depth) was also collected from Spring Creek Prairie from areas dominated by

Table 1. Soil characteristics at Spring Creek Prairie.

\begin{tabular}{|l|l|}
\hline $\begin{array}{l}\text { Soil } \\
\text { parameter }\end{array}$ & $\begin{array}{l}\text { Average } \\
\text { value }\end{array}$ \\
\hline $\mathrm{pH}$ & 6.7 \\
\hline $\begin{array}{l}\text { Organic matter } \\
\%\end{array}$ & 6.2 \\
\hline $\begin{array}{l}\text { Cation } \\
\text { exchange } \\
\text { capacity }\end{array}$ & 17.33 \\
\hline $\begin{array}{l}\text { Potassium } \\
\text { (mg/kg) }\end{array}$ & 1005 \\
\hline Sulfate & 16.3 \\
\hline Zinc (mg/kg) & 3.6 \\
\hline $\begin{array}{l}\text { Iron } \\
\text { (mg/kg) }\end{array}$ & 65.6 \\
\hline $\begin{array}{l}\text { Manganese } \\
\text { (mg/kg) }\end{array}$ & 4.73 \\
\hline $\begin{array}{l}\text { Copper } \\
\text { (mg/kg) }\end{array}$ & 2.24 \\
\hline $\begin{array}{l}\text { Calcium } \\
\text { (mg/kg) }\end{array}$ & 2424.3 \\
\hline $\begin{array}{l}\text { Magnesium } \\
\text { (mg/kg) }\end{array}$ & 311.6 \\
\hline $\begin{array}{l}\text { Sodium } \\
\text { (mg/kg) }\end{array}$ & 6.0 \\
\hline
\end{tabular}

B. inermis and S. scoparium and homogenized using a cement mixer till uniformly mixed and large root and litter debris was removed by hand. Soils at this site are very deep, well drained, and formed in calcareous till. Soils are mapped as Steinauer series and classified as fine-loamy, mixed, superactive, calcareous, mesic Typic Udorthents (Soil Survey Staff, accessed December 27, 2016). Other soil characteristics are summarized in Table 1.

\subsection{Soil amendment properties}

Litter, biochar, and sawdust samples of each soil amendment type were analyzed for carbon and nitrogen content. Litter, biochar, and sawdust samples were packed into $5 \times 9 \mathrm{~mm}$ tin capsules and $\% \mathrm{C}$ and $\% \mathrm{~N}$ was determined through combustion analysis on a Costech analytical ECS 4010. In this experiment the averages for $\% \mathrm{C}, \% \mathrm{~N}, \% \mathrm{P}, \% \mathrm{~K}, \mathrm{pH}$, and electrical conductivity (EC) for each soil amendment are summarized in Table 2. These measurements are found in other research examining the effect of grassland biochar on plant growth (van de Voorde et al. 2014b). Soil amendment treatments were standardized for differences in $\% \mathrm{C}$ so that all replicates received the same amount of $\mathrm{C}$. Based on an average aboveground net primary productivity (ANPP) of $400 \mathrm{~g}$ biomass/ $\mathrm{m}^{2} \mathrm{yr}$ in Midwestern grasslands (Knapp and Smith 2001 ) and the average $\% \mathrm{C}$ values of all soil amendment types $(48 \% \pm 1.07$, Table 2$), 1.09 \mathrm{~g}$ of $\mathrm{C}$ were added to each pot $(2.77 \mathrm{~g}$ litter/pot for $B$. inermis litter, $2.50 \mathrm{~g}$ litter/pot for $S$. scoparium litter, $2.32 \mathrm{~g} \mathrm{saw}-$ dust/pot, $2.24 \mathrm{~g}$ biochar/pot for B. inermis biochar, and $1.77 \mathrm{~g}$ biochar/pot for $S$. scoparium biochar). 
Table 2. Average soil amendment $\% \mathrm{C}, \% \mathrm{~N}, \mathrm{C}: \mathrm{N}$ ratio, $\% \mathrm{P}, \% \mathrm{~K}, \mathrm{pH}$, and electrical conductivity (EC). All means are $( \pm 1 \mathrm{SE})$. Letters indicate statistically significant differences among amendment types $(\mathrm{P}<0.05)$

\begin{tabular}{|c|c|c|c|c|c|c|c|}
\hline $\begin{array}{l}\text { Soil } \\
\text { amendment } \\
\text { type }\end{array}$ & $\% \mathrm{C}$ & $\% \mathbf{N}$ & $\begin{array}{l}\mathrm{C}: \mathrm{N} \\
\text { Ratio }\end{array}$ & $\% \mathbf{P}$ & $\% \mathrm{~K}$ & pH & EC \\
\hline $\begin{array}{l}\text { B. inermis } \\
\text { Biochar }\end{array}$ & $\begin{array}{l}48.69 \\
( \pm 0.14)^{a}\end{array}$ & $\begin{array}{l}1.48 \\
( \pm 0.01)^{\mathrm{d}}\end{array}$ & $\begin{array}{l}32.89 \\
( \pm 0.19)^{\mathrm{a}}\end{array}$ & $\begin{array}{l}0.27 \\
( \pm 0.003)^{d}\end{array}$ & $\begin{array}{l}0.41 \\
( \pm 0.01)^{\mathrm{d}}\end{array}$ & $\begin{array}{l}7.5 \\
( \pm 0.058)^{\mathrm{a}}\end{array}$ & $\begin{array}{l}0.31 \\
( \pm 0.009)^{\mathrm{a}}\end{array}$ \\
\hline $\begin{array}{l}\text { B. inermis } \\
\text { Litter }\end{array}$ & $\begin{array}{l}39.27 \\
( \pm 0.04)^{b}\end{array}$ & $\begin{array}{l}0.76 \\
( \pm 0.005)^{\mathrm{c}}\end{array}$ & $\begin{array}{l}51.89 \\
( \pm 0.43)^{b}\end{array}$ & $\begin{array}{l}0.13 \\
( \pm 0.005)^{\mathrm{b}}\end{array}$ & $\begin{array}{l}0.21 \\
( \pm 0.026)^{b}\end{array}$ & $\begin{array}{l}5.8 \\
( \pm 0.033)^{b}\end{array}$ & $\begin{array}{l}0.52 \\
( \pm 0.04)^{\mathrm{b}}\end{array}$ \\
\hline $\begin{array}{l}\text { S. scoparium } \\
\text { Biochar }\end{array}$ & $\begin{array}{l}61.57 \\
( \pm 0.15)^{c}\end{array}$ & $\begin{array}{l}1.07 \\
( \pm 0.007)^{\mathrm{b}}\end{array}$ & $\begin{array}{l}57.37 \\
( \pm 0.51)^{b}\end{array}$ & $\begin{array}{l}0.19 \\
( \pm 0.003)^{\mathrm{c}}\end{array}$ & $\begin{array}{l}0.32 \\
( \pm 0.012)^{\mathrm{c}}\end{array}$ & $\begin{array}{l}6.7 \\
( \pm 0.1)^{\mathrm{c}}\end{array}$ & $\begin{array}{l}0.29 \\
( \pm 0.014)^{\mathrm{a}}\end{array}$ \\
\hline $\begin{array}{l}\text { S. scoparium } \\
\text { Litter }\end{array}$ & $\begin{array}{l}43.54 \\
( \pm 0.02)^{d}\end{array}$ & $\begin{array}{l}0.49 \\
( \pm 0.004)^{\mathrm{a}}\end{array}$ & $\begin{array}{l}88.42 \\
( \pm 0.78)^{c}\end{array}$ & $\begin{array}{l}0.105 \\
( \pm 0.009)^{\mathrm{b}}\end{array}$ & $\begin{array}{l}0.17 \\
( \pm 0.003)^{b}\end{array}$ & $\begin{array}{l}5.6 \\
( \pm 0.033)^{b}\end{array}$ & $\begin{array}{l}0.45 \\
( \pm 0.029)^{\mathrm{b}}\end{array}$ \\
\hline Sawdust & $\begin{array}{l}46.94 \\
( \pm 0.07)^{e}\end{array}$ & $\begin{array}{l}0.48 \\
( \pm 0.02)^{\mathrm{a}}\end{array}$ & $\begin{array}{l}100.2 \\
( \pm 4.57)^{d}\end{array}$ & $\begin{array}{l}0.014 \\
( \pm 0.005)^{\mathrm{a}}\end{array}$ & $\begin{array}{l}0.076 \\
( \pm 0.009)^{\mathrm{a}}\end{array}$ & $\begin{array}{l}4.7 \\
( \pm 0.033)^{d}\end{array}$ & $\begin{array}{l}2.48 \\
( \pm 0.161)^{c}\end{array}$ \\
\hline
\end{tabular}

In standardizing for the amount of $\mathrm{C}$ being added to each treatment, the application rates for the biochar treatments corresponded to 4.4 ton/ha for $B$. inermis biochar and 3.4 ton/ha for $S$. scoparium. These application rates are relatively low compared to other studies who have used up to 100 ton/ha (Jha et al. 2010, Zimmerman et al. 2011). The C-based application of the soil amendments was chosen because different $\mathrm{C}$ levels in the soil may alter microbial $\mathrm{N}$ immobilization (Blumenthal et al. 2003), and because an addition Csource may promote growth of microorganisms that are generally thought to be $\mathrm{C}$ limited (Blumenthal et al. 2003). This correction for total $\mathrm{C}$ in each substrate does not account for potential differences in available $\mathrm{C}$ in each amendment type, however only recently have studies directly compared pyrolyzed and non-pyrolyzed grassland species (van de Voorde et al. 2014b, Schimmelpfennig et al. 2014). Furthermore some work has shown that pyrolysis temperature rather than feedstock type can influence volatile and fixed carbon content of biochar (Rajkovich et al. 2012) while other work has shown that any pulse of available $\mathrm{C}$ to the microbial community from low temperature biochar (like those used in this study) can be very short-lived (Smith et al.
2010). Electrical conductivity (EC) and $\mathrm{pH}$ measurements were taken on three replicate samples of the different soil amendments by mixing one gram of sample into $10 \mathrm{~mL}$ of DI water and both values were determined using a Thermo Fisher Orion Star A215 Dual $\mathrm{pH} /$ Electrical Conductivity meter. Potassium and phosphorus content were determined on three replicate samples of the different soil amendments first digesting the samples in acid and digests were then analyzed using a Thermo Fisher 6500 iCAP ICP emission spectrometer. $\mathrm{EC}, \mathrm{pH}, \% \mathrm{P}$, and $\% \mathrm{~K}$ measurements were conducted at Ward Laboratories, Inc (Kearney, NE).

\subsection{Soil amendments with J. virginiana seedlings}

The five soil amendment types (BL, NL, SD, BB, and NB) were mixed into the soil of each corresponding pot. Replicate pots were established. Pots were $8.5 \mathrm{~cm}$ in diameter, with ten replicate pots for each treatment (except for BB where only 8 pots had J. virginiana germination), as well as ten replicate control pots with no amendments. Exactly $250 \mathrm{~g}$ of soil (field weight) was added to each pot (average oven dry soil equivalent across all pots $225.11 \mathrm{~g}$ \pm 3.62 ). All pots were filled to the same level in the pots 
leading to an average bulk density of $0.945 \mathrm{~g} \mathrm{~cm}^{-3} \pm$ 0.002 across the treatments. No significant differences were found across treatment types in bulk density ( $\mathrm{P}$ $>0.05$ ) (BB: $0.936 \mathrm{~g} \mathrm{~cm}^{-3} \pm 0.003$; BL: $0.944 \mathrm{~g} \mathrm{~cm}^{-3} \pm$ 0.005; NB: $0.952 \mathrm{~g} \mathrm{~cm}^{-3} \pm 0.006$; NL: $0.954 \mathrm{~g} \mathrm{~cm}^{-3} \pm$ 0.004; SD: $\left.0.946 \mathrm{~g} \mathrm{~cm}^{-3} \pm 0.004\right)$.

Juniperus virginiana seeds were collected from The Nebraska National Forest and Grasslands, Bessey Nursery in Halsey, NE, and were planted into each of the 58 pots. Three seeds were initially added to each pot to ensure at least 1 viable seedling in each replicate pot. All pots had 1-2 seedlings germinated within 9-10 days after planting (except for the 2 pots removed from the final analysis where no seeds germinated). If two or more seedlings germinated, 1 seedling was chosen at random to keep in the pot; the others were weeded out by hand. Germination was followed for $\sim 3$ weeks after planting and if a seedling came up after the focal seedling had already been chosen, the new seedling was immediately removed by hand weeding. Data on seed weight were collected before planting, and there was no difference in average seed weight amongst the treatments $\left(\mathrm{F}_{5,52}=0.91 \mathrm{P}=0.482\right.$, $)$. At pot height the average light level present for the seedlings was $106.4 \mu$ moles $\bullet \mathrm{m}^{-2} \cdot \mathrm{s}^{-1}$. The pots were kept under 24-hour light in order to provide sufficient light for growth under these low-light conditions. Pots with seeds were watered every day at the beginning of the experiment and then watered only as needed when germination began. Water availability was maintained at high enough levels to ensure that $J$. virginiana seedlings were not subject to water stress. Seedlings were grown for 5 weeks, then harvested and air-dried to a constant weight at $65^{\circ} \mathrm{C}$. Both above- and below-ground biomass were measured, and allocation between above and belowground tissues was calculated as well. Soil ammonium $\left(\mathrm{NH}_{4}{ }^{+}\right)$and nitrate $\left(\mathrm{NO}_{3}-\right)$ levels were measured in all pots. At the time of plant ampling (5 week after planting) 20-25 g soil (wet weigt) was extracted in $50 \mathrm{~mL}$ of $1 \mathrm{M} \mathrm{KCI}$ solution.
Soil extract vials were shaken on a vial shaker for 30 minutes at a rate of $200 \mathrm{rpm}$. After settling overnight, the supernatant was sampled for $\mathrm{NH}_{4}+/ \mathrm{NO}_{3}$ - analysis at the University of Nebraska-Lincoln Ecosystem Analysis Laboratory. Extractable inorganic N content was determined colorimetrically using a Lachat QuickChem 8500 Series II.

\subsection{Statistical analysis}

We used one way ANOVAs to identify the differences among treatments in J. virginiana growth (total biomass, belowground biomass, and aboveground biomass) and soil nitrogen levels (both extractable $\mathrm{NH}_{4}^{+}$and $\mathrm{NO}_{3}^{-}$). Because we had an unbalanced design (8 replicates in the $\mathrm{BB}$ treatment, rather than 10 replicates in the other treatments), we utilized Type III sums of squares in our one-way ANOVAs (Shaw and Mitchell-Olds 1993). Pairwise comparisons among amendment types were evaluated using Games-Howell post-hoc tests (a modified post-hoc Tukey's test which accounts for unbalanced designs) (Games and Howell 1976). For these analyses, data were natural-log transformed to achieve normality. Linear regression analysis was conducted between soil amendment C: $\mathrm{N}$ ratio and $J$. virginiana biomass (total, above-, belowground biomass and proportional allocation between above and belowground structures). Linear regression analysis was also repeated with soil amendment $\% \mathrm{~K}$ and $\% \mathrm{P}$ as independent variables. For these regressions, biomass data were natural-log transformed to achieve normality. Because soil amendment $\mathrm{C}: \mathrm{N}$ ratio, $\% \mathrm{~K}$, and $\% \mathrm{P}$ measurements were determined before the start of the experiment, each $J$. virginiana data point was paired with the average soil amendment $\mathrm{C}: \mathrm{N}$ ratio, $\% \mathrm{~K}$, or $\% \mathrm{P}$ of its corresponding treatment. In order to examine the impact of biochar versus litter and native versus exotic grass species identity, we conducted a 
two-way ANOVA with soil amendment type (biochar or litter) and grass species (B. inermis or native) as fixed factors. For these two-way ANOVAs the sawdust and control treatments were excluded. Similar to our one-way ANOVAs, we utilized Type III sums of squares in our two-way ANOVA (Shaw and MitchellOlds 1993). All analysis was conducted using the statistical program $\mathrm{R}$ v 3.3.1.

\section{Result}

We examined the impact of soil amended with $B$. inermis biochar and B. inermis plant litter on $J$. virginiana success relative to soil amended with native grass biochar, native litter, sawdust, and unamended (control) soil. Overall we did not find strong evidence for an exotic-woody interaction specifically, however we did find that changes in the type of soil amendment (biochar vs. litter) had an impact on J. virginiana success. These soil amendment driven changes in J. virginiana performance were likely driven by changes in soil $\mathrm{N}$ availability associated with each treatment, as discussed below.

\subsection{Impact of soil amendment type on J. virginiana}

We found that across all treatments, the type of soil amendment significantly impacted total $J$. virginiana biomass $\left(\mathrm{F}_{5,52}=8.377, \mathrm{P}<0.001\right)$. While plant litter and sawdust reduced the total biomass of $J$. virginiana relative to the unamended control, biochar amendments did not significantly differ from the unamended control. Although the biochar treatments only marginally differed from the native litter treatments $(\mathrm{P}=$ 0.08 ) and the BL treatment did not differ from either biochar treatment, there was nearly a $45 \%$ difference in total biomass when comparing the biochar treatments to the litter treatments. These idiosyncratic differences in $J$. virginiana total biomass were largely driven by the lack of differences in root biomass across the amended treatments (although the J. virginiana root biomass in unamended control pots were significantly different from the litter and sawdust treatments) $\left(\mathrm{F}_{5,52}=\right.$ 4.898, $\mathrm{P}<0.001)$. The impact of soil amendment type on $J$. virginiana aboveground biomass were more apparent $\left(\mathrm{F}_{5,52}=8.877, \mathrm{P}<0.001\right.$; Figure 1$)$.

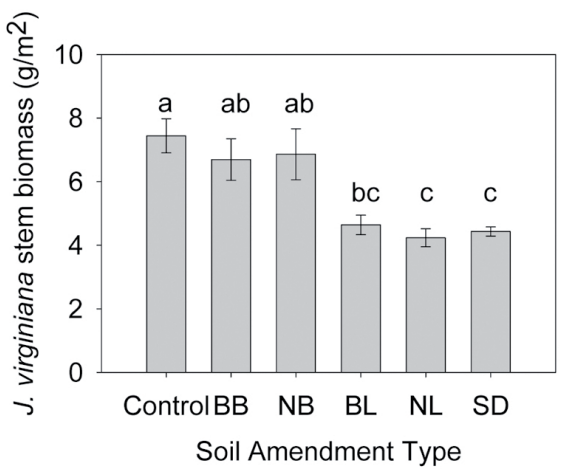

Figure 1. J. virginiana aboveground biomass across all treatments $(\mathrm{P}=7.28 \times 10-6)$. Error bars represent $\pm 1 \mathrm{SE}$. Letters indicate significant differences at an $\alpha$ level of 0.08 . All significantly different pairwise comparisons were significant at an $\alpha$ of 0.05 , except for 2 comparisons $\mathrm{NB}$ vs. $\mathrm{NL}(\mathrm{P}=0.073)$ and $\mathrm{BB}$ vs. $\mathrm{SD}(\mathrm{P}=0.052)$. Control: unamended soil; $\mathrm{BB}: B$. inermis biochar; NB: Native (S. scoparium) biochar; BL: B. inermis litter; NL: Native (S. scoparium) litter; SD: sawdust.

The biochar and unamended control pots did not differ from each other, but there was more than a 50\% decline in aboveground biomass in the litter treatments (Figure 1). While neither biochar type differed from BL treatment, BB did differ significantly from NL. These differences were largely due in part to the relatively higher variation in the NB treatment, which only had 8 replicates. 
Two-way ANOVAs demonstrated there was a significant main effect of soil amendment type (biochar vs. litter) on $J$. virginiana total biomass $\left(\mathrm{F}_{1,34}=4.18, \mathrm{P}\right.$ $=0.048)$, stem biomass $\left(\mathrm{F}_{1,34}=7.29, \mathrm{P}=0.01\right)$, proportional biomass allocation to roots $\left(\mathrm{F}_{1,34}=11.5, \mathrm{P}=\right.$ 0.002 ) and proportional biomass allocation to stems $\left(\mathrm{F}_{1,34}=9.40, \mathrm{P}=0.004\right)$. Total biomass in the biochar treatments was $8.99 \mathrm{~g} \mathrm{~m}^{-2}( \pm 0.675)$ whereas the litter treatment average was $6.25 \mathrm{~g} \mathrm{~m}^{-2}( \pm 0.28)$, a $44 \%$ difference (Figure 2).

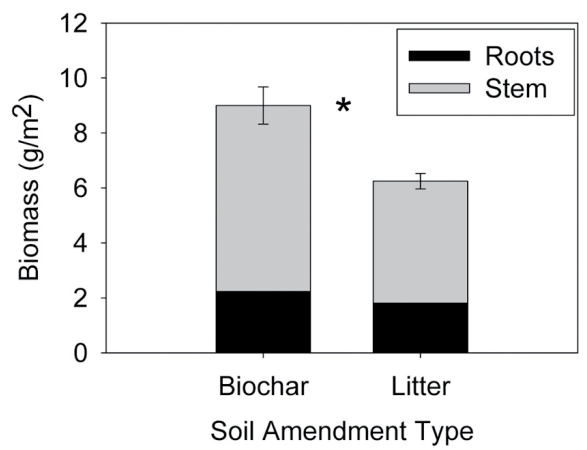

Figure 2. J. virginiana total biomass with unamended control and sawdust treatments excluded $(\mathrm{P}=0.048)$. Results from two-way analysis of variance (ANOVA) for soil amendment type (Biochar or Litter) and Grass species are shown (only soil amendment type was significant). Asterisk indicates significant difference between biochar and litter treatments $(\mathrm{P}<0.05)$. Black bar represents root biomass $\left(\mathrm{g} \mathrm{m}^{-2}\right)$. Gray bar represents stem biomass $\left(\mathrm{g} \mathrm{m}^{-2}\right)$. Error bars represent $\pm 1 \mathrm{SE}$ of total biomass.

This difference in total biomass was driven primarily by differences in stem biomass, with plants in the biochar treated pots producing $6.77 \mathrm{~g} \mathrm{~m}^{-2}( \pm 0.49)$ and plants in the litter treated pots producing $4.44 \mathrm{~g}$ $\mathrm{m}^{-2}( \pm 0.21)$, a greater than a $50 \%$ difference. There was no main effect of soil amendment type (biochar vs. litter) on root biomass $\left(\mathrm{F}_{1,34}=0.02, \mathrm{P}=0.89\right)$.
There was no main effect of grass species identity on any of the measured plant traits $(\mathrm{P}>0.05)$, and there were no significant soil amendment type $\mathrm{x}$ grass species interactions on any of the plant trait measurements $(\mathrm{P}>0.05)$. We found a weak yet significant negative relationship between average soil amendment $\mathrm{C}: \mathrm{N}$ ratio and total J. virginiana biomass $\left(\mathrm{F}_{1,46}=11.11, \mathrm{P}=0.0017\right.$; Adjusted $\mathrm{r}^{2}=0.18$ ) (Figure 3).

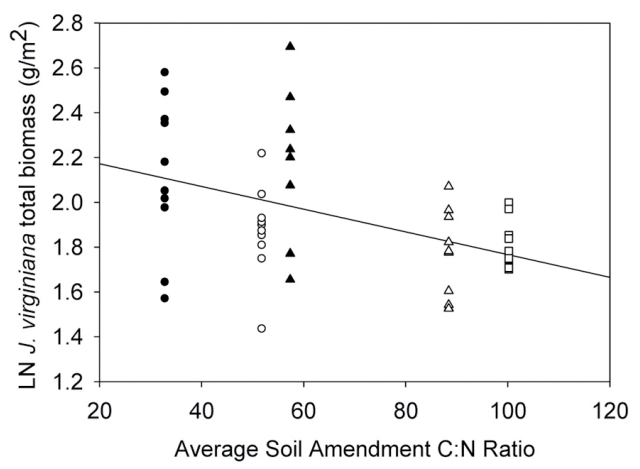

Figure 3. Regression analysis between average soil amendment $\mathrm{C}: \mathrm{N}$ ratio and total J. virginiana biomass $\left(\mathrm{g} \mathrm{m}^{-2}\right)\left(\mathrm{P}=0.0017\right.$; Adjusted $\left.\mathrm{r}^{2}=0.18\right)$. B. inermis litter (open circle); native litter (open triangle); $B$. inermis biochar (closed circle); native biochar (closed triangle); Sawdust (open square).

Stem biomass in particular was negatively related to average soil amendment $\mathrm{C}: \mathrm{N}$ ratio $\left(\mathrm{F}_{1,46}=12.5, \mathrm{P}\right.$ $<0.001$; Adjusted $\mathrm{r}^{2}=0.19$ ), while root biomass was only marginally related to the $\mathrm{C}: \mathrm{N}$ ratio $\left(\mathrm{F}_{1,46}=3.54\right.$, $\mathrm{P}=0.066$; Adjusted $\mathrm{r}^{2}=0.051$, data not shown). Soil amendment $\mathrm{C}: \mathrm{N}$ ratio had a very weak positive relationship with the percent of biomass allocated to roots $\left(\mathrm{F}_{1,46}=4.25, \mathrm{P}=0.045\right.$; Adjusted $\left.\mathrm{r}^{2}=0.065\right)$ but had no effect on allocation to stems $\left(\mathrm{F}_{1,46}=2.46, \mathrm{P}=0.12\right.$; Adjusted $\mathrm{r}^{2}=0.030$ ). We also found a weak positive relationship between soil amendment $\% \mathrm{~K}$ and total 
J. virginiana biomass $\left(\mathrm{F}_{1,46}=15.1, \mathrm{P}<0.001\right.$; Adjusted $\mathrm{r}^{2}=0.23$ ). Soil amendment $\% \mathrm{~K}$ had a weak positive relationship with stem biomass $\left(\mathrm{F}_{1,46}=13.9\right.$, $\mathrm{P}<0.001$; Adjusted $\left.\mathrm{r}^{2}=0.27\right)$ and no relationship to root biomass $\left(\mathrm{F}_{1,46}=3.42, \mathrm{P}=0.071\right.$; Adjusted $\mathrm{r}^{2}=$ $0.05)$. There was a weak positive relationship between $\% \mathrm{~K}$ and allocation to stems $\left(\mathrm{F}_{1,46}=6.1, \mathrm{P}=\right.$ 0.02 ; Adjusted $\mathrm{r}^{2}=0.09$ ) and a weak negative relationship between $\% \mathrm{~K}$ and allocation to roots $\left(\mathrm{F}_{1,46}=\right.$ $8.8, \mathrm{P}=0.005 ;$ Adjusted $\left.\mathrm{r}^{2}=0.14\right)$. Additionally, $\% \mathrm{P}$ and total $J$. virginiana biomass were significantly positively related $\left(\mathrm{F}_{1,46}=13.9, \mathrm{P}<0.001\right.$; Adjusted $\left.\mathrm{r}^{2}=0.22\right)$. Soil amendment $\% \mathrm{P}$ had a weak positive relationship with stem biomass $\left(\mathrm{F}_{1,46}=17.2, \mathrm{P}<\right.$ 0.001; Adjusted $\mathrm{r}^{2}=0.26$ ) and no relationship to root biomass $\left(\mathrm{F}_{1,46}=3.37, \mathrm{P}=0.073\right.$; Adjusted $\left.\mathrm{r}^{2}=0.05\right)$. There was a weak positive relationship between $\% \mathrm{P}$ and allocation to stems $\left(\mathrm{F}_{1,46}=5.2, \mathrm{P}=0.03\right.$; Adjusted $\left.\mathrm{r}^{2}=0.08\right)$ and a weak negative relationship between $\% \mathrm{P}$ and allocation to roots $\left(\mathrm{F}_{1,46}=7.7, \mathrm{P}=\right.$ 0.007; Adjusted $\mathrm{r}^{2}=0.13$ ).

\subsection{Impact of soil amendments on soil nitrogen}

Across all treatments, we found significant impacts on total inorganic $\mathrm{N}$ levels $\left(\mathrm{F}_{5,52}=71.44, \mathrm{P}\right.$ $<0.0001$ ), with both biochar treatments exhibiting significantly higher total inorganic $\mathrm{N}$ compared to all other treatments, including the unamended control (Figure 4). These differences in total inorganic $\mathrm{N}$ were driven by significant increases in $\mathrm{NH}_{4}^{+}$ levels in biochar-amended soils. While $\mathrm{NH}_{4}+$ levels in the NL and BL treatments did not differ from the sawdust treatment ( $\mathrm{P}=0.11$ and 0.41 , respectively) and the two biochar treatments did not differ from each other $(\mathrm{P}=0.999)$, the biochar treatments exhibited significantly higher $\mathrm{NH}_{4}+$ content than sawdust and both litter treatments $(\mathrm{P}<0.001)$ (Figure 4).

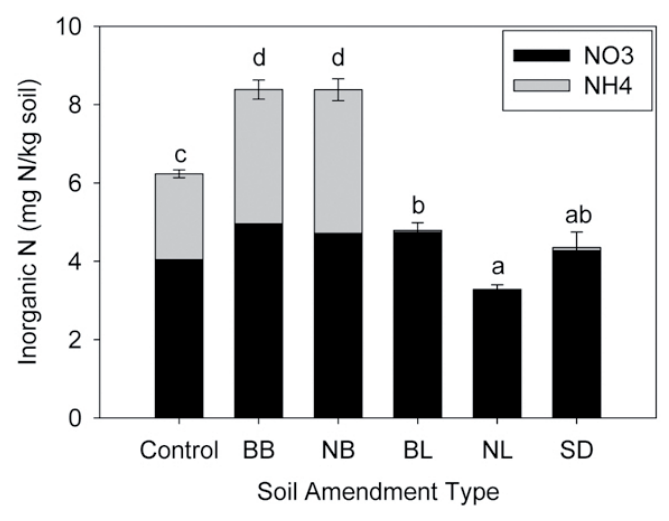

Figure 4. Total extractable inorganic soil $\mathrm{N}$ across all treatments (mg N/kg soil). Black bars represent $\mathrm{NO}_{3}$ and gray bars represent $\mathrm{NH}_{4}$. Error bars represent $\pm 1 \mathrm{SE}$ of mean total soil $\mathrm{N}$. Letters indicate significant differences in the total inorganic $\mathrm{N}$ among treatments $(\mathrm{P}<0.05)$. Control: unamended soil; $\mathrm{BB}$ : B. inermis biochar; NB: Native (S. scoparium) biochar; BL: B. inermis litter; NL: Native (S. scoparium) litter; SD: sawdust.

The average $\mathrm{NH}_{4}+$ level across the litter and sawdust treatments was $0.056 \mathrm{mg} \mathrm{NH}_{4}-\mathrm{N} / \mathrm{kg}$ soil while for the biochar treatments it was $3.53 \mathrm{mg} \mathrm{NH}-\mathrm{N} / \mathrm{kg}$ soil. Furthermore, $\mathrm{NH}_{4}+$ levels in the $\mathrm{BB}$ and $\mathrm{NB}$ treatments were $56 \%$ and $67 \%$ higher than the unamended control, respectively. For soil $\mathrm{NO}_{3}$ - levels, there was a significant impact across all treatments $\left(\mathrm{F}_{5,52}=13.03\right.$, $\mathrm{P}<0.001$ ), however these differences were smaller in magnitude than the differences in $\mathrm{NH}_{4}+$, and were not the major drivers of observed differences in total inorganic N (Figure 4).

The two-way ANOVA comparing the effects of soil amendment type (biochar vs. litter) and species origin (native vs. exotic) confirmed that soil amendment type had the largest impact on soil $\mathrm{NH}_{4}+\left(\mathrm{F}_{1,34}=239.8, \mathrm{P}<0.001\right)$ and total inorganic $\mathrm{N}\left(\mathrm{F}_{1,34}=135.2, \mathrm{P}<0.001\right)$. 
Soil $\mathrm{NH}_{4}+$ levels in the biochar treated pots were 2 orders of magnitude higher than the litter treated pots (Figure 5), while soil $\mathrm{NO}_{3}$ - was unaffected by soil amendments type $\left(\mathrm{F}_{1,34}=1.33, \mathrm{P}=0.25\right)$.

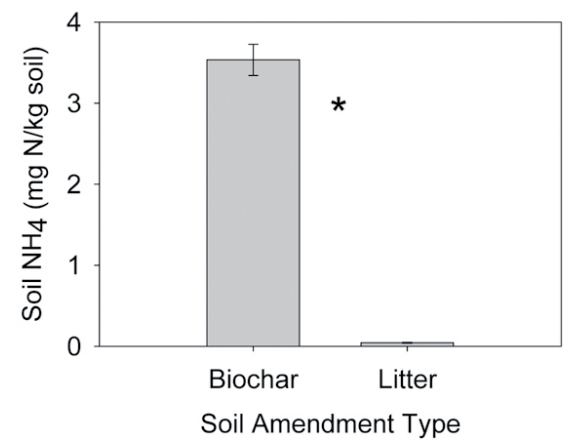

Figure 5. Extractable $\mathrm{NH}_{4}$ levels (mg N/kg soil) with unamended control and sawdust treatments excluded $\left(\mathrm{P}<2 \times 10^{-16}\right)$. Results from two-way analysis of variance (ANOVA) for soil amendment type (Biochar or Litter) and Grass species are shown (only soil amendment type was significant). Asterisk indicates significant difference between biochar and litter treatments $(\mathrm{P}<0.05)$. Error bars represent $\pm 1 \mathrm{SE}$ of soil $\mathrm{NH}_{4}$ level.

Since there was no significant grass species effect on soil $\mathrm{NH}_{4}+\left(\mathrm{F}_{1,34}=0.03, \mathrm{P}=0.86\right)$, or on soil $\mathrm{NO}_{3}{ }^{-}\left(\mathrm{F}_{1,34}\right.$ $=1.47, \mathrm{P}=0.23)$, the total inorganic $\mathrm{N}$ did not vary by species $\left(F_{1,34}=0.0003, P=0.98\right)$. However, the effect of soil amendment type on total inorganic $\mathrm{N}$ did vary by species (soil amendment type $\mathrm{x}$ grass species interaction; $\mathrm{F}_{1,34}=27.8, \mathrm{P}<0.001$ ), primarily because soil $\mathrm{NO}_{3}^{-}$was reduced by native litter but not by $B$. inermis litter or by either species' biochar (soil amendment type $\mathrm{x}$ grass species interaction; $\mathrm{F}_{1,34}=20.5$, $\mathrm{P}$ $<0.001$; Figure 6). Figure 6 demonstrates that total inorganic $\mathrm{N}$ is affected by a significant interaction between grass species identity and soil amendment type that is being driven by between-species differences in the litter treatment.
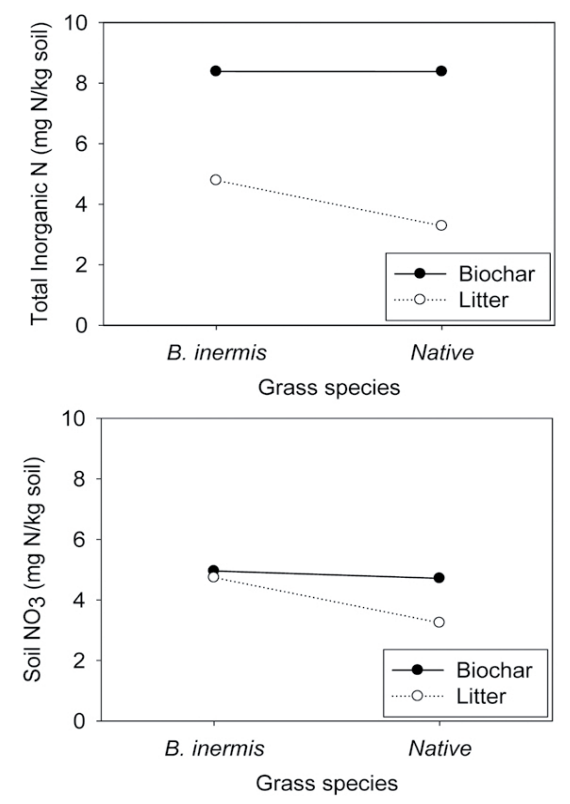

Figure 6. Extractable inorganic total N (top) (soil amendment type $\mathrm{x}$ grass species interaction, $\mathrm{P}<7.5 \mathrm{x}$ $10^{-6}$ ) and $\mathrm{NO}_{3}$ (bottom) (soil amendment type $\mathrm{x}$ grass species interaction, $\mathrm{P}=6.9 \times 10^{-5}$ ) with unamended control and sawdust treatments excluded. Results from two-way analysis of variance (ANOVA) for soil amendment type (Biochar or Litter) and Grass species (B. inermis and Native) are shown. Symbols represent mean levels in each treatment (Litter: open circles; Biochar: closed circles).

Total inorganic $\mathrm{N}$ differs between the two species when litter is added, but those differences disappear when litter is converted to biochar before being added to the soil. The average total inorganic $\mathrm{N}$ in both the BB treatment and NB treatment was $8.38 \mathrm{mg} \mathrm{N} /$ $\mathrm{kg}$ soil, whereas the BL treatment was $4.78 \mathrm{mg} \mathrm{N} / \mathrm{kg}$ soil and the NL treatment was $3.28 \mathrm{mg} \mathrm{N} / \mathrm{kg}$ soil. For soil $\mathrm{NO}_{3}-$, species differences in both biochar treatments are minimal, with $\mathrm{BB}$ having $4.96 \mathrm{mg} \mathrm{N} / \mathrm{kg}$ soil and the NB treatment having $4.71 \mathrm{mg} \mathrm{N} / \mathrm{kg}$ soil. 
Species differences in soil $\mathrm{NO}_{3}^{-}$can more clearly be seen in the litter treatments with NL treatment having $3.24 \mathrm{mg} \mathrm{N} / \mathrm{kg}$ soil and BL treatments having $4.74 \mathrm{mg}$ $\mathrm{N} / \mathrm{kg}$ soil (Figure 6).

\section{Discussion}

In our experiment we provide evidence that $J$. virgin$i a n a$, a rapidly expanding woody species in US grasslands, may grow significantly faster in soil amended with biochar compared to soil amended with native or exotic grass litter, as seen by the more than $40 \%$ increase in $J$. virginiana biomass in the biochar addition treatments. Furthermore we found that biochar feedstock type did not have an impact on the effect of biochar, as both native and exotic grass biochar had similar positive impacts on soil $\mathrm{N}$ levels and $J$. virginiana growth as compared to litter amended soils.

Our results demonstrate that $J$. virginiana growth is impacted by the type of soil amendment (biochar or litter). The increase in plant biomass found in this study following biochar application to soil is consistent with other studies examining biochar impact on plant growth, particularly increases in aboveground structures with biochar addition (Biederman and Harpole 2013). Additionally, our results are consistent with other findings that the addition of biochar from grassland species does not have the same negative impact that litter additions can have on plant growth as compared to the unamended control soil (van de Voorde et al. 2014b). In contrast with van de Voorde et al. (2014b), who found species specific impacts of grassland biochar on plant growth, we found that the two biochar types had similar impacts on plant growth. However van de Voorde et al. (2014b) utilized biochar derived from grassland species that were much more dissimilar (i.e. forbs) than we did in this study, which may explain these differing results. The observed differences in J. virginiana growth in soils with biochar amendments as compared to soils amended with plant litter may have been influenced by the more than 2 order of magnitude increase in available $\mathrm{NH}_{4}+$ in the biochar treatments (Figure 5) given the impact that $\mathrm{N}$ availability can have in grassland systems (Laungani and Knops 2009), although changes in the availability of other nutrients, such as K and P, may have also contributed (van de Voorde et al. 2014a). Increases in soil nutrient levels with biochar additions, and declines in soil $\mathrm{N}$ with litter additions have been found in other work as well (Bowman et al. 2004, McElligott et al. 2011, Laungani and Knops 2012).

Increased soil $\mathrm{NH}_{4}+$ levels associated with the biochar treatments could have been driven by a number of mechanisms including, increased gross and net $\mathrm{N}$ mineralization from soil organic matter, low nitrification rates, low microbial $\mathrm{N}$ immobilization, or by high $\mathrm{NH}_{4}+$ adsorption (as reviewed by Clough et al. 2013). Our work does not allow us to unequivocally determine a single key mechanism driving the increased $\mathrm{NH}_{4}+$ levels because inorganic $\mathrm{N}$ was only measured once during the course of the experiment.

Biochar additions have been shown to impact many of the underlying processes that drive inorganic $\mathrm{N}$ availability in the soil (Clough et al. 2013). For example, some recent work has shown increases in gross and net mineralization and nitrification (Nelissen et al. 2012). Concurrently other work has shown little to no effect on these processes (or even declines) in response to biochar additions (Clough et al. 2013). These inconsistent changes in $\mathrm{N}$ cycling rates may be driven by a complex suite of interactions between factors such as (but not limited to) biochar feedstock type, pyrolysis temperature, cation exchange capacity of both the soil and biochar, and other soil properties such as $\mathrm{pH}$ (Clough et al. 2013). Biochar addition could have also directly increased $\mathrm{NH}_{4}+$ in the soil, but given the extremely small amount of material added we find this explanation unlikely; the amount of $\mathrm{N}$ added 
in the form of biochar was approximately $0.02 \mathrm{~g}$ ( $\sim 2 \mathrm{~g}$ biochar with $\sim 1 \% \mathrm{~N}$ content) in a 250 -g pot of soil. Our results are most consistent with the mechanism of increased $\mathrm{NH}_{4}+$ adsorption in biochar amended soils (Taghizadeh-Toosi et al. 2012, Clough et al. 2013), but we do not presume that the observed increase in $\mathrm{NH}_{4}+$ levels in our biochar pots exclude changes to these other unmeasured interactions and processes, but merely offer one plausible mechanism.

Given the impact that non-pyrolyzed $\mathrm{C}$ additions to soil can have on the growth of invasive species via changes in $\mathrm{N}$ availability (Blumenthal et al. 2003) we were interested in understanding whether the $\mathrm{C}: \mathrm{N}$ ratio of our pyrolyzed and non-pyrolyzed soil amendments could be used as a predictor for $J$. virginiana success. While increasing $\mathrm{C}: \mathrm{N}$ ratio of non-pyrolyzed soil amendments (i.e. litter and sawdust) has been associated with reduced $\mathrm{N}$ availability via increased microbial $\mathrm{N}$ immobilization (Bowman et al. 2004, Laungani and Knops 2012) and subsequent declines in plant growth (Bowman et al. 2004, Suding et al. 2004), biochar C:N ratio was found to be a poor predictor of plant productivity (Biederman and Harpole 2013) and therefore may or may not impact rates of microbial $\mathrm{N}$ immobilization (Clough et al. 2013). Taken together, this may help explain the weak but significant negative relationship that was observed between amendment $\mathrm{C}: \mathrm{N}$ ratio and J. virginiana total biomass. Additionally, this suggests that the observed relationship between $\mathrm{C}: \mathrm{N}$ ratio and J. virginiana total biomass, must be interpreted cautiously. In order to more fully understand the potential impacts of biochar on plant growth, a thorough mechanistic understanding of biochar impacts on inorganic $\mathrm{N}$ levels and the underlying $\mathrm{N}$ cycling processes must be carefully examined. In regards to our litter treatments, our results agree with many studies reporting an species-specific impact of litter on $\mathrm{N}$ availability (Chapman et al. 2006, Laungani and Knops 2009) (Figure 6). In our study native litter reduced $\mathrm{NO}_{3}$ - levels compared to B. inermis litter and biochar treatments, but once litter was converted to biochar, native plant material no longer reduced soil $\mathrm{NO}_{3}$ - and soil $\mathrm{NO}_{3}$ - levels in the biochar treatments did not differ from the unamended soil. This suggests that any species-specific litter impacts on plant growth may be eliminated in the process of biochar production (Bowman et al. 2004).

Overall, our results demonstrate that biochar amendments to soil may positively impact the growth of $J$. virginiana seedlings, whereas litter amendments negatively impact $J$. virginiana growth relative to unamended control soils. Soil application of biochar vs. litter impacted inorganic $\mathrm{N}$ levels in the soil which may have subsequently driven to the observed differences in $J$. virginiana seedling growth. If biochar additions to soils are being used as a management technique in grasslands (van de Voorde et al. 2014b), biochar derived from grasses (exotic or native) may impact plant community composition in these ecosystems and therefore must be examined closely as a climate change mitigation strategy before being applied to grassland soils.

\section{Acknowledgments}

This work was funded by Nebraska EPSCoR Research Experiences for Undergraduates at Small Colleges. We would like acknowledge Jesse Koenig for initial pilot work that inspired this work. We would also like to acknowledge Dr. Sasha Wright, Dr. Joe Mascaro, and Dr. Nicole Miller-Struttman, for their insightful comments on earlier versions of the manuscript. We would also like to acknowledge Billy Garver at Doane College for R coding help, Cathleen McFadden at the University of Nebraska-Lincoln Ecosystem Analysis Laboratory for sample analysis, Nick Ward at Ward 
Laboratories, Inc for soil amendment analysis, and Rich Gilbert of the Nebraska Forest Service for providing J. virginiana seeds.

\section{References}

Adams, M. M., T. J. Benjamin, N.C. Emery, S.J. Brouder, K.D. Gibson. 2013. The Effect of Biochar on Native and Invasive Prairie Plant Species. Invasive Plant Science and Management. 6, 97-207.

Biederman, L. A., and W. S. Harpole. 2013. Biochar and its effects on plant productivity and nutrient cycling: a meta-analysis. GCB Bioenergy. 5, 202-214.

Blumenthal, D. M., N. R. Jordan, and M. P. Russelle. 2003. Soil carbon addition controls weeds and facilitates prairie restoration. Ecological Applications. 13, 605-615.

Bowman, W. D., H. Steltzer, T. N. Rosenstiel, C. C. Cleveland, and C. L. Meier. 2004. Litter effects of two co-occurring alpine species on plant growth, microbial activity and immobilization of nitrogen. Oikos. 104,336-344.

Chapman, S. K., J. A. Langley, S. C. Hart, and G. W. Koch. 2006. Plants actively control nitrogen cycling: uncorking the microbial bottleneck. New Phytologist. 169, 27-34.

Clough, T. J., L. M. Condron, C. Kammann, and C. Müller. 2013. A review of biochar and soil nitrogen dynamics. Agronomy. 3, 275-293.

Curaqueo, G., S. Meier, N. Khan, M. Cea, and R. Navia. 2014. Use of biochar on two volcanic soils: effects on soil properties and barley yield. Journal of soil science and plant nutrition. 14, 911-924.

Games, P. A., and J. F. Howell. 1976. Pairwise Multiple Comparison Procedures with Unequal N's and/or Variances: A Monte Carlo Study. Journal of Educational and Behavioral Statistics. 1, 113-125.
Jha, P., A. K. Biswas, B. L. Lakaria, and A. S. Rao. 2010. Biochar in agriculture-prospects and related implications. Current science. 99, 1218-1225.

Knapp, A. K., J. M. Briggs, S. L. Collins, S. R. Archer, M. S. Bret-Harte, B. E. Ewers, D. P. Peters, D. R. Young, G. R. Shaver, E. Pendall, and M. B. Cleary. 2008. Shrub encroachment in North American grasslands: shifts in growth form dominance rapidly alters control of ecosystem carbon inputs. Global Change Biology. 14, 615-623.

Knapp, A. K., and M. D. Smith. 2001. Variation Among Biomes in Temporal Dynamics of Aboveground Primary Production. Science. 291, 481-484.

Laungani, R., and J. M. H. Knops. 2009. Speciesdriven changes in nitrogen cycling can provide a mechanism for plant invasions. Proceedings of the National Academy of Sciences of the United States of America. 106, 12400-12405.

Laungani, R., and J. M. H. Knops. 2012. Microbial immobilization drives nitrogen cycling differences among plant species. Oikos. 1840-1848.

Lehmann, J., and S. Joseph. 2009. Biochar for environmental management: An introduction. Pages 1-12. Biochar for environmental management: Science and technology. Earthscan, London.

Lehmann, J., Y. Kuzyakov, G. Pan, and Y. Ok. 2015. Biochars and the plant-soil interface. Plant and Soil. 1-5.

McElligott, K., D. Page-Dumroese, and M. Coleman. 2011. Bioenergy production systems and biochar application in forests: potential for renewable energy, soil enhancement, and carbon sequestration. Res. Note RMRS-RN-46. Fort Collins, CO.

Nelissen, V., T. Rütting, D. Huygens, J. Staelens, G. Ruysschaert, and P. Boeckx. 2012. Maize biochars accelerate short-term soil nitrogen dynamics in a loamy sand soil. Soil Biology and Biochemistry. 55, 20-27. 
Norris, M. D., J. M. Blair, and L. C. Johnson. 2007. Altered ecosystem nitrogen dynamics as a consequence of land cover change in tallgrass prairie. American Midland Naturalist. 158, 432-445.

Ohsowski, B. M., J. N. Klironomos, K. E. Dunfield, and M. M. Hart. 2012. The potential of soil amendments for restoring severely disturbed grasslands. Applied Soil Ecology. 60, 77-83.

Rajkovich, S., A. Enders, K. Hanley, C. Hyland, A. R. Zimmerman, and J. Lehmann. 2012. Corn growth and nitrogen nutrition after additions of biochars with varying properties to a temperate soil. Biology and Fertility of Soils. 48, 271-284.

Schimmelpfennig, S., C. Müller, L. Grünhage, C. Koch, and C. Kammann. 2014. Biochar, hydrochar and uncarbonized feedstock application to permanent grassland-Effects on greenhouse gas emissions and plant growth. Agriculture, Ecosystems \& Environment. 191, 39-52.

Shaw, R. G., and T. Mitchell-Olds. 1993. ANOVA for unbalanced data: an overview. Ecology. 74, 1638-1645.

Siemann, E., and W. E. Rogers. 2003. Changes in light and nitrogen availability under pioneer trees may indirectly facilitate tree invasions of grasslands. Journal of Ecology. 91, 923-931.

Smith, J. L., H. P. Collins, and V. L. Bailey. 2010. The effect of young biochar on soil respiration. Soil Biology and Biochemistry. 42, 2345-2347.
Suding, K. N., J. R. Larson, E. Thorsos, H. Steltzer, and W. D. Bowman. 2004. Species effects on resource supply rates: do they influence competitive interactions?. Plant Ecology. 175, 47-58.

Taghizadeh-Toosi, A., T. Clough, R. Sherlock, and L. Condron. 2012. Biochar adsorbed ammonia is bioavailable. Plant and Soil. 350, 57-69.

Vinton, M. A., and E. M. Goergen. 2006. Plant-soil feedbacks contribute to the persistence of Bro

Vinton, M. A., and E. M. Goergen. 2006. Plant-soil feedbacks contribute to the persistence of Bromus inermis in tallgrass prairie. Ecosystems. 9, 967-976.

Van de Voorde, T. F. J., T. M. Bezemer, J. W. Van Groenigen, S. Jeffery, and L. Mommer. 2014a. Soil biochar amendment in a nature restoration area: effects on plant productivity and community composition. Ecological Applications. 24, $1167-1177$

Van de Voorde, T. F. J., F. van Noppen, R. W. Nachenius, W. Prins, L. Mommer, J.-W. Van Groenigen, and T. M. Bezemer. 2014b. Biochars produced from individual grassland species differ in their effect on plant growth. Basic and Applied Ecology. $15,18-25$.

Zimmerman, A. R., B. Gao, and M.-Y. Ahn. 2011. Positive and negative carbon mineralization priming effects among a variety of biochar-amended soils. Soil Biology and Biochemistry. 43, 1169-1179. 